\title{
EFL Teachers' Phonological Awareness Beliefs and Practices: Help or Prevent EFL Children Developing Reading
}

\author{
Yousef Alshaboul $^{1 *} \quad$ Randa Almahasneh ${ }^{2}$ \\ Elsayed Elshabrawi Ahmed Hassanein ${ }^{2}$ Sayed Ibrahim ${ }^{2}$ \\ 1. College of Education, Qatar University, Doha, Qatar. P.O. Box 2713, Doha-Qatar \\ 2. College of Education, Qatar University, Doha, Qatar
}

\begin{abstract}
EFL teachers' proficiency seems to contribute to the reading difficulties that early graders encounter. This paper investigates the knowledge, beliefs, practices and awareness in phonological awareness (PA) of twohundred and ten ramdonly selected EFL in-service teachers and then examines the impact of teachers' experiences, qualifications, and gender on shaping teachers' instruction. The researchers used a four-section survey to collect teachers' demographic information, perceived and actual knowledge of phonological awareness and classroom practices related to PA, phonics, and syllabication. The results reported teachers as moderate level in the beliefs, practice and awareness of PA. In terms of teachers' knowledge in PA, however, results showed teachers lacking the basics in teaching reading. Implications for EFL teacher education and preparation are highlighted.
\end{abstract}

Keywords: EFL, in-service teachers, deficits, reading, phonological awareness.

DOI: $10.7176 / \mathrm{JEP} / 10-12-09$

Publication date: April $30^{\text {th }} 2019$

\section{Introduction}

The role teachers assume in the development of children's literacy skills is undeniable (Hindman \& Wasik, 2008; Lee, Cawthon \& Dawson, 2013); conscientious teachers work hard to help early graders crack the code and handle print effortlessly (Foulin, 2005; Hindman \& Wasik, 2008; Vadasy, Sanders, \& Peyton, 2006). Since the No Child Left Behind Act of 2001 (NCLB), the literacy bar in the United States has been on the rise for schools who are now accountable for helping children read at the appropriate grade level. This forced schools to implement different ways and means to improve reading skills, among which was to focus on and instruct children explicitly in phonological awareness (PA).

In the case of learning English as a foreign language (EFL), achieving grade-level literacy creates a challenge for EFL children. Research reports different challenges that EFL children experience while learning to read in English. Some of those challenges are apparent in the pre-lexical word recognition processes requiring lexical items to activate semantic, syntactic, and pragmatic associations when reading English texts (Brown \& Hyness, 1985; Fender, 2003; Ryan \& Meara, 1991). Research asserts the need for these processes to function properly at the pre-lexical stage due to their role in identifying and activating a word or a lexical item, a step deemed crucial for reading fluency and comprehension in the second language (Eskey, 1988; MacDonald, 2000; Perfetti, 1985; Siedenberg, 1992; Stanovich, 1993).

Research demonstrates that a child equipped with substantial knowledge and skills in PA has a better opportunities of becoming a good reader than a child who is not (Cárnio, Vosgrau \& Soares, 2017). In fact, Yopp (1992) stresses the children's need to develop an awareness of and skills in manipulating the language sounds and that PA is the part that the majority of young learners lack the most. This in fact points fingers at the classroom instruction to reason whether the quality of instruction children receive in their classrooms help or delay their emergence into reading, asituation that shifts responsibility to classroom teachers and holds them accountable.

In 1994, Moats led a study to investigate teachers' efficiency to teach reading; Moats reported that teachers did face difficulties when answering questions on basics in reading. Those results attracted the attention of scholars in the field and led a flow of research investigating teachers' adequacy to teach reading (Kennedy, 2013). Unfortunately, the findings of such research studies confirmed Moats' statement; sevral researchers expressed their concern for seeing some teachers confused about some fundamentals in PA and unaware of its relationship with developing reading skills (Moats, 2009; Washburn, Joshi, Cantrell, 2011a, 2011b; Washborn, Mulcahy \& Musante, 2017).

While Hindman and Wasik (2008) concur with the critical role of the instruction, interaction and exposure teachers deliver to early graders, Ponitz and Rimm-Kaufman (2011) argue that teachers should be accountable for the quality of literacy instruction they deliver in their classrooms. This stance received more support from latter research and mounted to a campaign calling for helping teachers to develop more effective teaching practices that would facilitate early graders' emergence into literacy (Cárnio, Vosgrau \& Soares, 2017, Catts, Fey, Zhang, \& Tomblin, 2008; Connor, Jakobsons, Crowe \& Meadows, 2009; Hindman \& Wasik, 2008; Huffman \& Speer, 2000; Morris, 2011; Piasta \& Wagner, 2010; Spear-Swerling, 2011). Scholars have realized the necessity for this research 
as long as inclusive information has not been reached yet (Carlisle, Kelcey, Rowan, \& Phelps, 2011).

Therefore, this research paper grounds itself within the framework solicited by the National Reading Panel report (2000) and the subsequent research that perceive PA as a key component in the development of reading skills where phonics, phonemic awareness, fluency, vocabulary, and comprehension are considered essential literacy components and central for literacy development.

\subsection{The Context of the Study}

In Jordan, the Ministry of Education required English instruction for all students beginning at age six. The expectation for students is that upon graduation from school, Jordanian students will have met high standards for English language and literacy proficiency. However, several sources of data suggest that this expectation is not being met (Author et al., 2013). The achievement levels of Jordanian students has been declining over the last decade on international measures of academic achievement such as the TIMSS assessments (Alhabahba, 2016; Mullis, Martin, Foy and Arora, 2012). The PISA reports also indicate that Jordanian students tend to score lower than the international average in reading (PISA, 2012). The Education First English Proficiency Index (2014), an organization that examines and ranks the average level of English skills in students from the Middle East and North Africa (MENA), indicates that since 2007, MENA's average English proficiency level is decreasing, and Jordan in particular has been rated as a 'very low proficiency' region since 2013.

This situation raises concerns about the reasons behind this drawback; more than anytime ever, it directs attention to the quality of instruction teachers deliver in the classroom. In spite of the abundant literature available on the role of classroom teachers in instructing children in phonological awareness from different language backgrounds, the case is different concerning children speaking Arabic as their first language in the Middle East. Alghazo and Al-Hilawani (2010) report that the available literature on Arabs does not cover the different domains especially the role of phonological awareness in developing reading. Research on this particular topic is still lacking.

Therefore, this paper targets the efficiency of classroom instruction and practices of the Jordanian EFL teachers and its role in the development of children's reading skills. Specificlly, it investigates the Jordanian inservice EFL teachers' knowledge in, beliefs about, practices and awareness of PA when instructing EFL early graders in English language. In other words, this study targets the teachers of English language as a probable cause.

\section{Literature Review}

Research confirms a substantial relationship between PA instruction and reading development; research consideres it critical to instruct learners in certain preliminary language skills perceiving PA as a reliable indicatore for students' future reading proficiency (Adams \& Bruck, 1995; Blachman, 2000; Bos, Mather, Dickson, Podhajski, \& Chard, 2001; Cárnio, Vosgrau \& Soares, 2017; Driver et al., 2014; Juel, 1988; Kennedy et al., 2013Snow, Griffin \& Burns, 2005; Richgels, 2001Verhoeven, 2000; Verhoeven \& Leeuwe, 2011). However, there are differences and variations in clasrrom instruction among EFL teachers manifest in the different reading proficiency levels that students achieve. McCutchen et al. (2002) theorize that teachers' instructional practices are the byproduct of the deep understanding and knowledge they possess, and qonsequently, students' performance would mirror the knowledge, beliefs and practices of their instructors (Moats \& Foorman, 2003). While researchers recommend that teachers base their classroom practices on solid research-proved beliefs and knowledge (Frey, Lee, Tollefson, Pass, \& Massengill, 2005), teachers instruct young children depending on their own experience, prudence and good judgment (Chen, 2010; Morris, 2011; Wharton-McDonald, 2011).

Central to this study is the assumption that teachers' beliefs affect the type and quality of classroom instruction (Hindman \& Wasik, 2008). As a concept, beliefs most probably connect with the presumptions, principles, and points of view an individual embraces regarding certain matters (Evans, Fox, Cremaso, \& McKinnon, 2004). Beliefs as a term has emerged in research investigating teachers' instructional practices (Hoy, Tarter \& Hoy, 2006). According to Hindman and Wasik (2008), inner beliefs steer and generate individuals' actions and reactions.

For knowledge, literature provides evidence that teachers lack the basics in teaching reading to early graders (Abbot, Walton, \& Greenwood, 2002; Kennedy, 2013; Mather, Box, \& Babur, 2001; Troyer \& Yopp, 1990; Washborn, Mulcahy \& Musante, 2017). Extant literature ponders the possibility of connecting reading failure and the literacy instruction delivered to children in classrooms vs. PA. Could teachers' lack of adequate knowledge and efficient classroom practices contribute to the children's poor performance in reading? Such a concern drove McCutchen et al. (2003) to investigate the relationships among early-grade teachers and reading-related content, philosophy steering reading instruction, classroom practice, and students' learning. Results confirmed a correlation between instructional philosophy, content knowledge and classroom practices; results stressed the need for providing teachers with opportunities to develop the necessary knowledge and skills to teach reading effectively.

In their investigation of teachers' beliefs, awareness, and knowledge about phonological awareness, Cunningham and her colleagues (2004) concluded that teachers' instruction is vulnerable to their perceived level of knowledge and negative beliefs. This in turn would result in misrepresentations for phonological content matters 
leading to a confusion among learners, a conclusion that holds teachers accountable for the quality of their instruction. Richards and Lockhart (1994) state, "what teachers do is a reflection of what they know and believe, and "teacher knowledge" and "teacher thinking" provide the underlying framework or schema which guides the teacher's classroom actions (p. 29).

Tibi (2005) examined the teachers' knowledge and skills in PA on a sample of 145 early-grade teachers in the United Arab Emirates. Tibi reported that early-grade teachers demonstrated weakness in knowledge and skills in phonological awareness and lacked readiness to instruct students properly. Al-Hazza (2008) reported similar results when investigating the perceived knowledge of phonics and phonological awareness among 141 fulltime teachers. Results indicated statistical significant differences between the participants of low-rated and high-rated knowledge in both phonological awareness and phonics. In there turn, Alghazo and Al-Hilawani (2010) reported almost the absence of teaching materials in phonological awareness, a hint to the absence of phonological awareness as a concept from the whole teaching-learning process.

Teachers' knowledge and beliefs earn prominence due to the teachers' critical role in exposing children to a literacy-rich environment that shapes their learning (Hindman \& Wasik, 2008). However, the way teachers act in classrooms is not always based on research-proved procedures and practices. It is strongly believed that the kind of teaching experience those teachers were exposed to when being students themselves could be the main reason behind the way they teach and the beliefs they hold (Holt-Reynolds, 1992; Kagan, 1992; Pajares, 1992). Other scholars concluded that some teachers do not even think of changing their classroom practices; instead, their beliefs and practices got fossilized and entrenched in their past experience (Powell, 1992; Tatto, 1998; Wubbels, 1992); teachers' former experience shapes and decides on their daily performance (Cheng \& Zamarro, 2016).

\subsection{Questions of the Study}

This study aimed to answer the following two main questions:

1) What do EFL teachers' report in terms of their knowledge, their beliefs, their awareness and their teaching practices associated with PA?

2) Are there any statistically significant differences in EFL teachers' PA knowledge beliefs, awareness, and practice due to gender, experience and academic qualifications?

\section{Methodology}

\subsection{Participants}

Two hundred and ten $(\mathrm{F}=101, \mathrm{M}=109)$ in-service EFL language teachers participated in the study. Table 1 details the participants' distribution in terms of gender, academic qualifications, and years of teaching experience . Participants were solicited from either the graduate courses they were enrolled in or were reached in their schools. All participant teachers graduated from English language departments from different universities in the country.

Table 1. The Distribution of Teachers' Gender, Qualifications, and Experiences

\begin{tabular}{llll}
\hline Variable & Qualification & Frequency & Percent \\
\hline Gender & Male & 109 & 52 \\
& Female & 101 & 48 \\
Qualification & Bachelor (BA) & 160 & 76.2 \\
& BA and Higher Diploma & 22 & 10.5 \\
& Masters (MA) and above & 28 & 13.3 \\
Experience (Years) & $1-3$ & 68 & 32.2 \\
& $4-7$ & 35 & 16.6 \\
Total & $8-11$ & 52 & 24.6 \\
& 12 and more & 55 & 26.1 \\
\hline
\end{tabular}

\subsection{Study Tools}

The researchers administered a four-part modified survey version of Preschool Literacy Practices Checklist (Burgess et al, 2001). The four components included demographic information, teachers' knowledge, beliefs and practices of PA. Teachers' actual knowledge of PA was measured using a modified version of phonics pretest (Dow $\&$ Baer, 2006). The pretest included questions from three categories of early literacy development related to phonological awareness, phonics, and syllabication. Teachers responded to the 24-item test through identifying, locating and counting sounds in words in a multiple-choice format. Each correct response weighs one point out of 24. In the case of beliefs, awareness and practices of PA, teachers were asked to indicate their level of agreement to various statements using a five-point Likert scale ranging from strongly disagree $=1$, to strongly agree $=5$. The entire survey took approximately thirty-five minutes to complete.

The tool was checked for validity through consulting a panel of three university professors and five teachers in the field EFL. All recommendations and suggestions were used to modify the questionnaire and produce the 
final version.

For reliability purposes, the researchers administered the tool to a group of 30 teachers and administered it again after 15 days. The correlation coefficient between the test-retest was computed yielding 0.84 , a value considered acceptable for the purpose of the study.

\section{Data Analysis and Results}

Question One. What do EFL teachers' report in terms of their knowledge, their beliefs, their awareness and their teaching practices associated with PA?

Reporting results followed the order of the four components as stated in the question. The first component in question one targeted the participants' knowledge. With few exceptions, results indicated that most participants' responses were very low.

The lowest score participants received was 3 while the highest was 19 out of 24 , yielding an average $M=8.73$ and a $\mathrm{SD}=2.54$. Only items $13,3,1,5,17,9$ scored above 0.50 . Table 2 shows the results of the knowledge test items and the means and the standard deviations of the teachers' performance.

Table 2. Means and Standard Deviations of Items Knowledge Test about PA

\begin{tabular}{|c|c|c|c|}
\hline Item & Question & Mean & SD \\
\hline 13 & A phoneme refers to $\ldots$ & .75 & .37 \\
\hline 3 & The letter " $\mathrm{i}$ " in the word "sife" probably sounds like the " $\mathrm{i}$ " in ... & .70 & .39 \\
\hline 1 & $\begin{array}{l}\text { A word that contains a short vowel sound is ... } \\
\text { a. treat b. start c. slip d. cold e. point }\end{array}$ & .70 & .39 \\
\hline 5 & The word "eight" has ............. speech sounds. & .67 & .40 \\
\hline 17 & When you put the sounds $/ \mathrm{sh} /$ and /oe/ together,. you are . & .65 & .41 \\
\hline 9 & A word that has the sound /c/ similar to the initial sound of the word "seal" is & .65 & .41 \\
\hline 22 & The word "shook" has ............. sounds. & .43 & .42 \\
\hline 7 & The word "grass" has .. & .38 & .42 \\
\hline 10 & The pair of words that begins with the same sound is ... & .35 & .41 \\
\hline 20 & $\ldots$ is a pronounceable group of letters that contain a vowel sound. & .35 & .41 \\
\hline 21 & The word "edge" has .............. sounds & .35 & .41 \\
\hline 16 & When you say the word "cat" without the/c/sound, you are ... & .34 & .41 \\
\hline 4 & A pair of a voiceless-voiced consonant is ... & .34 & .41 \\
\hline 14 & $\begin{array}{l}\text { A combination of two or three consonants pronounced so that each letter keeps its own } \\
\text { identity is called a ... }\end{array}$ & .31 & .40 \\
\hline 2 & The only word among the following that does not have a silent letter is . & .26 & .38 \\
\hline 11 & When reversing the production of the sounds of the word "ice" it sounds like ... & .22 & .36 \\
\hline 12 & When reversing the sounds of the word "enough" it sounds almost like ... & .22 & .35 \\
\hline 18 & A false statement in the following is that phonological awareness is ... & .18 & .33 \\
\hline 6 & The word "box" has ............. speech sounds. & .18 & .33 \\
\hline 24 & The word "dictionary" has .............. sounds. & .17 & .32 \\
\hline 8 & The second sound in the word "queen" is ... & .17 & .32 \\
\hline 23 & The word "university" has .............. sounds. & .14 & .30 \\
\hline 15 & Two combined letters that represent one single speech sound are a . & .13 & .29 \\
\hline \multirow[t]{2}{*}{19} & $\begin{array}{l}\text {........ is a reading method that focuses on teaching the application of speech sounds } \\
\text { to letters. }\end{array}$ & .10 & .26 \\
\hline & All test Items & 8.73 & 2.54 \\
\hline
\end{tabular}

Teachers' beliefs, about instructing EFL learners in PA ranged between 3.10 and 4.10, totaling an average score of 3.72 , and $\mathrm{SD}=.41$. Although none of the means scored higher or close to 5.00 , none scored below 3.00 . The top participants' response was item three that asks whether students' ability to recognize letters should be consdiered as a strong predictor of early reading success $(M=4.10, S D=.79)$. The second highest scoring item $(M=4.00, S D=.89)$ focused on the importance of students spending time with letters or words. On the other hand, participants' lowest response was on item six, "Phonemic awareness and phonics mean essentially the same thing" $(M=3.10, S D=1.00)$. The next lowest scored item was their response to item seventeen "I am a phonics master," $(M=3.16, S D=.89)$. Table 3 shows the results. 
Table 3. Means and Standard deviations for Beliefs about instructing EFL learners in PA

\begin{tabular}{|c|c|c|c|}
\hline Item & I believe that ... & Mean & SD \\
\hline 3 & Students' ability to recognize letters is a strong predictor of early reading success. & 4.10 & .79 \\
\hline 26 & It is important that students spend time write letters or words. & 4.00 & .89 \\
\hline 5 & $\begin{array}{l}\text { Individual differences in phonological awareness help explain child's reading } \\
\text { owth. }\end{array}$ & 3.92 & .80 \\
\hline 15 & It is important to recognize words by sight. & 3.90 & .97 \\
\hline 21 & It is important that students spend time sounding out words & 3.88 & .86 \\
\hline 23 & It is important that students compare words and word parts in heard words. & 3.87 & .93 \\
\hline 1 & Students' ability to rhyme words is a strong predictor of early reading success. & 3.85 & .90 \\
\hline 2 & It is important that students spend time reciting rhymes, songs, or poems. & 3.82 & .89 \\
\hline 25 & It is important that students categorize printed words based on spelling patterns. & 3.81 & .85 \\
\hline 24 & It is important that students categorize heard words based on sound patterns. & 3.80 & .87 \\
\hline 12 & It is important that I demonstrate segmenting words into phonemes when reading. & 3.80 & .79 \\
\hline 14 & Teaching students to decode words is one of my most important goals. & 3.79 & .85 \\
\hline 18 & Phonics needs to be taught directly to beginning readers to become fluent readers. & 3.78 & .92 \\
\hline 19 & It is important that students spend time naming letters. & 3.78 & .89 \\
\hline 20 & It is important that students spend time finding letters in words. & 3.76 & .91 \\
\hline 11 & I know how to teach phonics. & 3.74 & .90 \\
\hline 13 & It is important to teach decoding (phonics) strategies. & 3.73 & .80 \\
\hline 22 & It is important that students compare words and word parts in printed words & 3.71 & .87 \\
\hline 4 & Poor phonemic awareness inhibits learning to read. & 3.70 & .94 \\
\hline 9 & I know how to teach phonological awareness. & 3.62 & .93 \\
\hline 16 & It is important to use context to pronounce an unknown word. & 3.59 & 1.13 \\
\hline 10 & I know how to assess phonological awareness. & 3.53 & .84 \\
\hline 8 & The best approach in teaching reading is Phonics. & 3.44 & .97 \\
\hline 7 & The best approach in teaching reading is Whole Language. & 3.44 & 1.08 \\
\hline 17 & I am a phonics master & 3.16 & .89 \\
\hline 6 & Phonemic awareness and phonics mean essentially the same thing. & 3.10 & 1.00 \\
\hline
\end{tabular}

Concerning the third part of question one, the phonological awareness, participants' responses were relatively moderate with an average of 3.12, and $\mathrm{SD}=.71$. Item means ranged between $(M=3.34)$ and $(M=3.04)$ with standard deviations ranging between $(S D=3.07)$ and $(S D=.83)$. Participants' highest response was on item 10 , "I know how to teach segmenting," $(M=3.34, S D=3.07)$ while their lowest response was on item eleven, "I know how to teach blending," $(M=3.04, S D=.83)$. Table 4 shows the results.

Table 4. Means and Standard Deviations for Awareness of PA

\begin{tabular}{llll}
\hline Item & Statement & Mean & SD \\
\hline 10 & I know how to teach segmenting. & 3.34 & 3.07 \\
1 & I know what rhyming is. & 3.33 & .97 \\
6 & Segmenting is important. & 3.32 & 1.00 \\
5 & Rhyming is important. & 3.27 & 1.13 \\
2 & I know what segmenting is. & 3.23 & .89 \\
7 & Blending is important. & 3.19 & .96 \\
9 & I know how to teach rhyming. & 3.19 & .98 \\
13 & I know how to assess rhyming. & 3.18 & .95 \\
8 & Deletion is important. & 3.18 & .89 \\
14 & I know how to assess segmenting. & 3.18 & .87 \\
16 & I know how to assess deletion. & 3.16 & .87 \\
4 & I know what deletion is. & 3.14 & .95 \\
15 & I know how to assess blending. & 3.11 & .85 \\
3 & I know what blending is. & 3.10 & .78 \\
12 & I know how to teach deletion. & 3.08 & .89 \\
11 & I know how to teach blending. & 3.04 & .83 \\
\hline & All Items & 3.12 & .71 \\
\hline
\end{tabular}

The last part in question one targeted participants' practices. A quick look at the results reveals that participants' responses were relatively high with an average of 3.59 , and $\mathrm{SD}=.51$. The item with the highest mean response was, "My students' reading varies due to individual differences in phonological awareness," $(M=4.07$, $S D=3.9$ ), while the lowest mean response was, "When teaching, I don't differentiate between phonemic awareness 
and phonics," $(M=2.98, S D=1.03)$. Table 5 reports the results.

Table 5. Means and Standard Deviations for Practices of PA

\begin{tabular}{|c|c|c|c|}
\hline Item & Practices & Mean & SD \\
\hline 5 & $\begin{array}{l}\text { My students' reading varies due to individual differences in phonological } \\
\text { awareness. }\end{array}$ & 4.07 & 3.9 \\
\hline 3 & I practice letter recognition with my students. & 4.00 & .75 \\
\hline 1 & I practice rhyming with my students. & 3.88 & .89 \\
\hline 4 & My students suffer in reading because of their poor phonemic awareness. & 3.82 & 1.07 \\
\hline 26 & I have students spend time write letters or words. & 3.75 & 1.0 \\
\hline 22 & I have students spend time comparing words and word parts in printed words. & 3.75 & .95 \\
\hline 21 & I have students spend time sounding out words. & 3.70 & .93 \\
\hline 19 & I have students spend time naming letters. & 3.69 & .91 \\
\hline 25 & I have students spend time categorize printed words based on spelling patterns. & 3.64 & .92 \\
\hline 20 & I have students spend time finding letters in words & 3.63 & 1.02 \\
\hline 16 & I urge students to use context to pronounce an unknown word. & 3.61 & .99 \\
\hline 23 & I have students spend time comparing words and word parts in heard words. & 3.58 & 1.00 \\
\hline 15 & I teach students to recognize words by sight. & 3.56 & 1.00 \\
\hline 7 & I adopt the whole language approach in teaching reading. & 3.55 & 1.13 \\
\hline 2 & I have students spend time reciting rhymes, songs, or poems. & 3.53 & 1.04 \\
\hline 24 & I have students spend time categorizing heard words based on sound patterns. & 3.52 & 1.02 \\
\hline 14 & I strongly emphasize teaching my students to decode. & 3.50 & .85 \\
\hline 11 & I teach phonics in my class. & 3.50 & .99 \\
\hline 8 & I adopt phonics in teaching reading. & 3.50 & 1.00 \\
\hline 9 & I teach my students' phonemic awareness. & 3.50 & .95 \\
\hline 17 & My teaching reflects my command in phonics. & 3.50 & .96 \\
\hline 10 & I assess my students' phonemic awareness. & 3.47 & .91 \\
\hline 18 & I teach phonics directly to beginning readers to become fluent, skillful readers. & 3.46 & 1.10 \\
\hline 13 & I teach phonics strategies to my students. & 3.39 & .94 \\
\hline 12 & I demonstrate how to segment words into phonemes when reading. & 3.36 & .89 \\
\hline \multirow[t]{2}{*}{6} & When teaching, I do not differentiate between phonemic awareness and phonics. & 2.98 & 1.03 \\
\hline & All Items & 3.59 & .51 \\
\hline
\end{tabular}

Question Two. Are there any statistically significant differences in EFL teachers' PA knowledge beliefs, awareness, and practice due to gender, experience and academic qualifications?

The second question of the study seeks significant effects for the independent variables (gender, experience, qualifications) on in-service EFL teachers' beliefs about, awareness of and knowledge in phonological awareness. Therefore, the researchers used the multivariate MANOVA test because it can produce a significant main effect on the independent constructs when working in combination; the variables will be more meaningful taken together than considered separately.

Upon running the MANOVA test, the Wilks' Lambda results showed significant differences $(P<0.05)$ for the independent variables on the dependent variables. In details, MANOVA revealed a significant multivariate main effect for gender, Wilks' $\lambda=.89, \mathrm{~F}=5.75, \mathrm{p}<0.05$, partial eta squared $=.11$. Similar to this, experience yielded a Wilks' $\lambda$ of $=.82, F=3.16, p<0.05$, partial eta squared $=.06$. On the other hand, teachers' qualifications did not reveal any significance. Further, the results for the interactions among the independent variables showed significant effects including the interaction between gender and experience, gender and qualification, experience with qualification, and gender with experience and qualification. Table 6 shows the results of MANOVA analysis.

Table 6. MANOVA Test Results

\begin{tabular}{|c|c|c|c|c|}
\hline Effect & Wilks' Lambda & $\mathrm{F}$ & Sig. & $\begin{array}{l}\text { Partial } \\
\text { Eta }\end{array}$ \\
\hline Gender & .89 & 5.75 & .000 & .11 \\
\hline Experience & .82 & 3.16 & .000 & .06 \\
\hline Qualification & .94 & 1.61 & .120 & .03 \\
\hline Gender * Experience & .75 & 4.82 & .000 & .09 \\
\hline Gender * Qualification & .86 & 3.61 & .000 & .07 \\
\hline Experience $*$ Qualification & .73 & 2.57 & .000 & .08 \\
\hline Gender * Experience * Qualification & .88 & 6.69 & .000 & .13 \\
\hline
\end{tabular}

Since a significant multivariate main effect for gender and experience has been obtained, data analysis should proceed to run the univariate $F$ tests to look at each dependent variable in turn to see if the independent variable has a significant impact on them separately. Table. 7 shows the results of univariate analysis of gender on all dependent variables. 
Table 7. Univariate Analysis of Gender on Teachers' Knowledge, Beliefs, Practice, Awareness.

\begin{tabular}{|c|c|c|c|c|c|c|c|}
\hline Dependent Variable & Gender & Means & Type III Sum of Squares & $\mathrm{df}$ & Mean Squares & $\mathrm{F}$ & Sig. \\
\hline \multirow[t]{2}{*}{ Knowledge } & Female & 8.89 & .37 & 1 & .37 & .062 & .80 \\
\hline & Male & 9.48 & & & & & \\
\hline \multirow[t]{2}{*}{ Beliefs } & Female & 3.83 & 2.46 & 1 & 2.46 & 16.282 & .00 \\
\hline & Male & 3.61 & & & & & \\
\hline \multirow[t]{2}{*}{ Practice } & Female & 3.73 & 2.53 & 1 & 2.53 & 10.202 & .00 \\
\hline & Male & 3.45 & & & & & \\
\hline \multirow[t]{2}{*}{ Awareness } & Female & 3.42 & 3.62 & 1 & 3.62 & 7.450 & .01 \\
\hline & Male & 3.05 & & & & & \\
\hline
\end{tabular}

In light of the analysis carried out, gender was a factor that plays a significant role on EFL in-service teachers' beliefs, awareness and practices with higher means for females. The only area that gender did not show significant effect was on the teachers' knowledge.

Univariate analysis was performed to examine the effect of teachers' experience on their knowledge, beliefs, awareness and practice. Results are shown in table 8 .

Table 8. Univariate Analysis of Experience on Knowledge, Beliefs, Awareness, and Knowledge

\begin{tabular}{|c|c|c|c|c|c|c|}
\hline Dependent Variable & Experience & Means & Type III Sum of Squares & df Mean Square & $\mathrm{F}$ & Sig. \\
\hline \multirow{4}{*}{ Knowledge } & $1-3$ & 9.32 & 65.11 & $\begin{array}{ll}3 & 21.71\end{array}$ & 3.59 & .02 \\
\hline & $4-7$ & 9.56 & & & & \\
\hline & $8-11$ & 8.06 & & & & \\
\hline & $12+$ & 9.23 & & & & \\
\hline \multirow[t]{4}{*}{ Beliefs } & $1-3$ & 3.68 & 1.37 & 3.46 & 3.02 & .03 \\
\hline & $4-7$ & 3.59 & & & & \\
\hline & $8-11$ & 3.74 & & & & \\
\hline & $12+$ & 3.84 & & & & \\
\hline \multirow[t]{4}{*}{ Practice } & $1-3$ & 3.59 & .28 & 3.09 & .38 & .77 \\
\hline & $4-7$ & 3.51 & & & & \\
\hline & $8-11$ & 3.63 & & & & \\
\hline & $12+$ & 3.57 & & & & \\
\hline \multirow[t]{4}{*}{ Awareness } & $1-3$ & 3.33 & 1.66 & 3.55 & 1.14 & .33 \\
\hline & $4-7$ & 3.18 & & & & \\
\hline & $8-11$ & 3.22 & & & & \\
\hline & $12+$ & 3.10 & & & & \\
\hline
\end{tabular}

As shown in table 8, teachers' experience affected their knowledge and beliefs in phonological awareness. Post hoc tests were used to test which of the apparent differences in teachers' knowledge and beliefs among the four levels of experience are significant. Post hoc tests showed significant differences only between teachers with (4-7) years of experience and teachers with (8-11) years of experience on knowledge. Interestingly, knowledge about phonological awareness is better for teachers with (4-7) years of experience. In terms of beliefs, post hoc test shows significant differences only between teachers of (4-7) and 12+ years of experience, with the later outperforming the first.

As previously shown in table 6 , significant effects of the interactions among the study independent variables were found, including, the interaction of gender with experience $(\mathrm{F}=4.82)$, gender with qualification $(\mathrm{F}=3.61)$, qualification with experience $(\mathrm{F}=2.57)$, and gender with both experience and qualification $(\mathrm{F}=6.70)$, all $\mathrm{F}$ values are at $\mathrm{p} 0<0.05$. Therefore, further univariate $\mathrm{F}$ tests were performed to determine if each of these interactions has significant effect on the dependent variables (i.e. knowledge, beliefs, practice and awareness). The univariate analyses of the effect of the interaction of gender with experience, showed significant effect on knowledge, beliefs and practices ( $\mathrm{F}=13.48,4.80,3.80$, respectively). Likewise, the interaction between experience and qualification showed significant effect on knowledge, beliefs and practices $(\mathrm{F}=4.13,2.23,2.34$, respectively). In addition, the interaction between gender, experience and qualification showed significant effect on knowledge, beliefs and practices $(\mathrm{F}=16.58,6.98,4.68$, respectively). While, the interaction between gender and qualification showed significant effect only on knowledge and practice ( $\mathrm{F}=5.40,3.83$, respectively). All reported $\mathrm{F}$ values are at $\mathrm{p}<0.05$. Furthermore, post hoc comparisons were performed to identify the subgroups with significant differences. Post hoc comparisons however, did not follow regular patterns. Plot Figures 1, 2, 3, 4, and 5 are examples of the effect of the interactions between the study independent variables on the dependent variables. Examples of the lack of regular patterns is shown in Figure 1. While females of 1-3 years of experience scored higher than the other years of experience, males of 4-7 scored higher than the other sub groups. Similar results could be found in Figure 2, which shows the interaction between gender and qualification. While female master students perform better than males in terms of their qualification, female students with bachelor and diploma degree perform the lowest among other subgroups. 


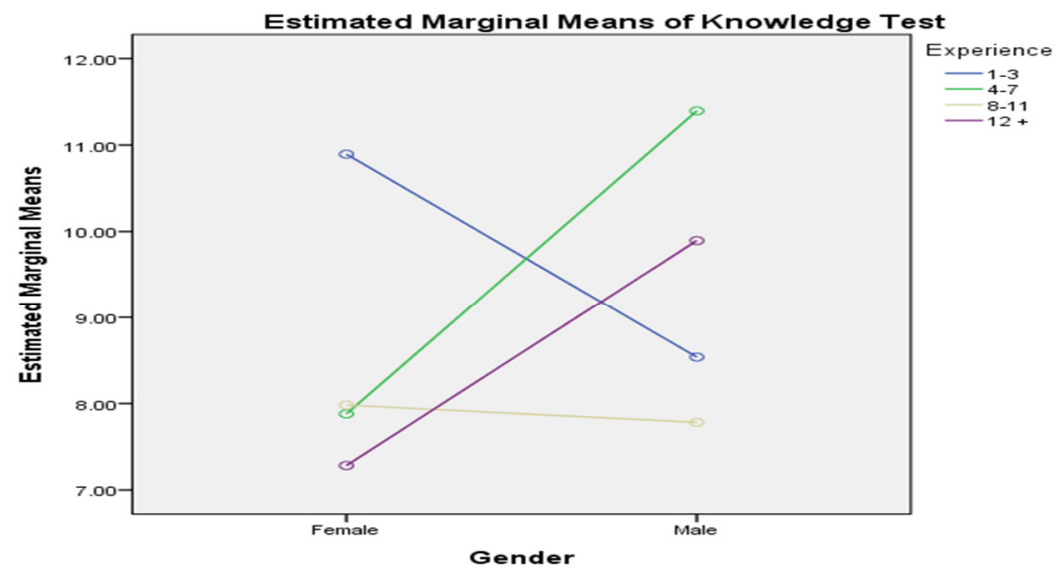

Figure 1. The interaction between gender and experience on knowledge test.

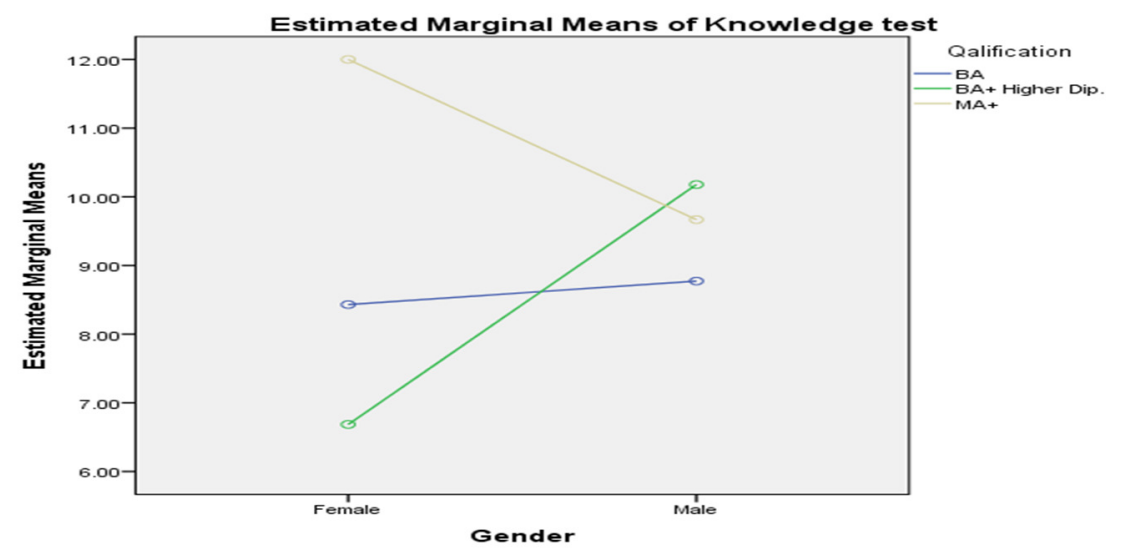

Figure 2. The interaction between gender and qualification on knowledge test.

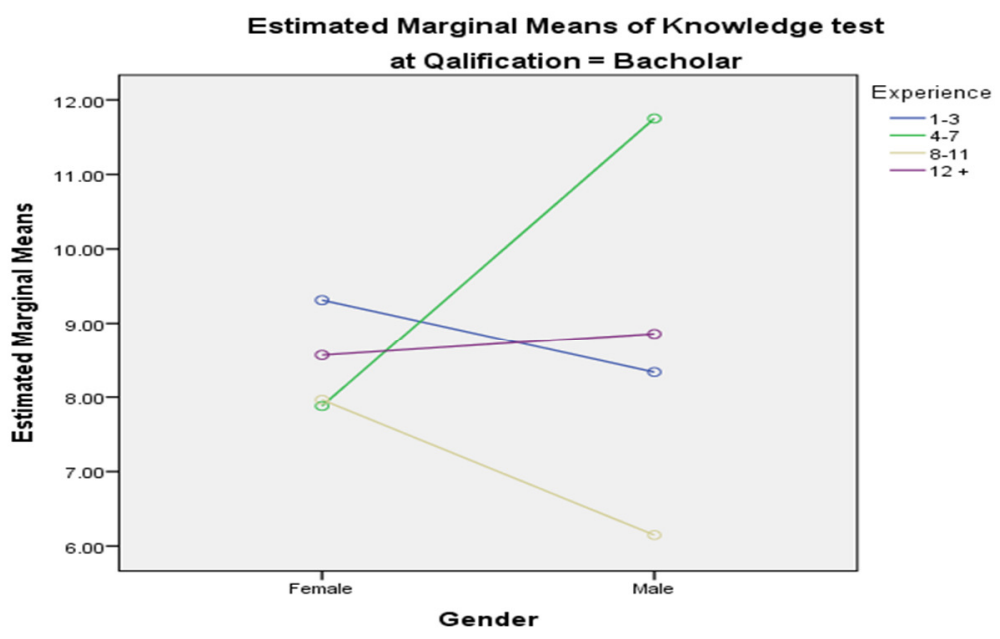

Figure 3. Interaction between Gender, Experience and Qualification on Knowledge Test 


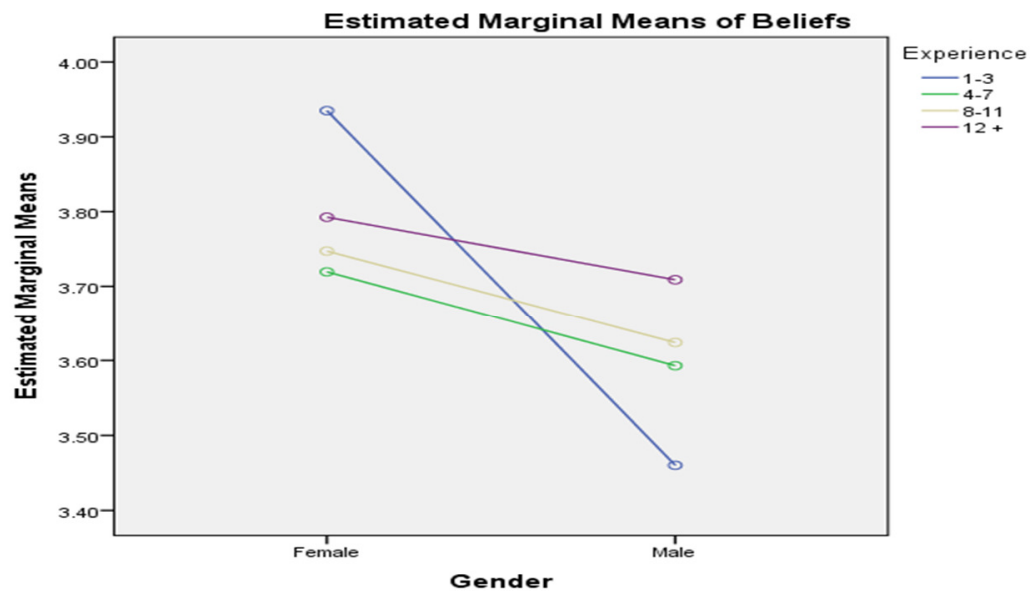

Figure 4. The interaction between Gender and Experience on Beliefs

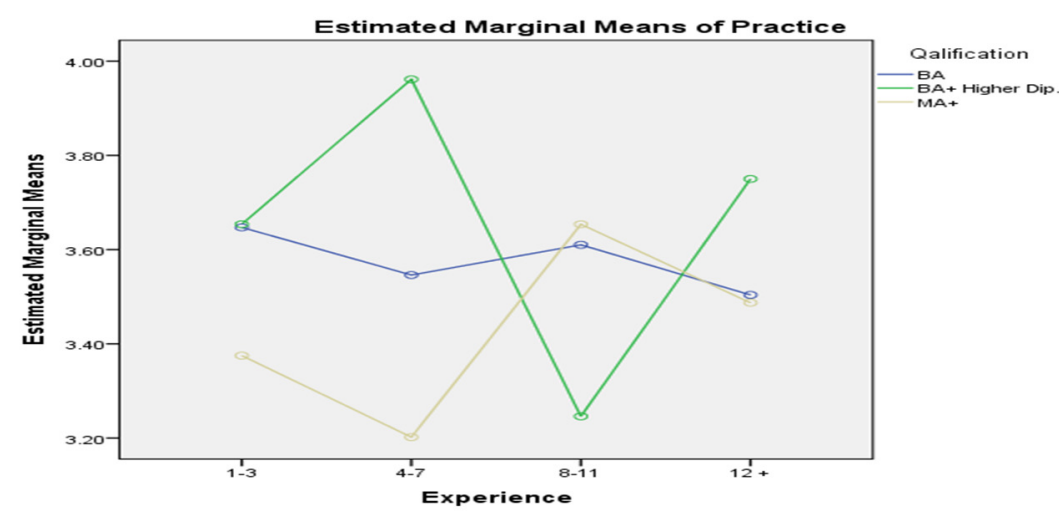

Figure 5 The effect of the interaction between Experience and Qualification on Practice of PA

\section{Discussion}

This study embraces the role of teacher preparation in developing primary-grade children reading skills (Morris, 2011; Spear-Swerling, 2011; Yopp, 1992). It is common that reading is the greatest challenge that children face early in their lives. Actually, researchers believe that struggling children during 1-3 are more likely to continue to have stuggles throughout their schooling experience (Francis, Shaywitz, Stuebing, Shaywitz \& Fletcher, 1996; Snow, Burns \& Griffin, 1998). Adams and Bruck (1995), Blachman (2000), Bos et al. (2001) and Juel (1988) linked low literacy levels to deficiencies in the basic literacy skills. To reiterate, this work stems from the researchers' belief that teachers' classroom instruction could contribute to the low literacy-level of our EFL children.

In general, the findings of this study pertinent to the first question indicate that most EFL teachers lack the basics in reading instructions. For example, for EFL teachers to fail to recognize the differences between phonics and phonemic awareness indicates that teachers do not offer a rich environment and practices that provide opportunities for children to play with the sounds of the language. This in turn indicates a shortage in teachers' repertoire of the knowledge, skills and strategies. This echoes similar findings in the literature where researchers raised concerns about teachers being confused about certain fundamentals in PA and were unable to link that to the development of childrens' reading skills (Moats, 2009; Washburn, Joshi, Cantrell, 2011a, 2011b; Washborn, Mulcahy \& Musante, 2017). The results of this study concerning participants' knowledge in PA were surprising and concerning. The majority of the teachers could not pass the knowledge test. One would conclude that instead of providing adequate instruction, these EFL teachers disservice children and contribute to their failure.

Regarding EFL teachers' beliefs, it is evident that the participants did not develop strong principles about the effectiveness of PA on the development of reading. The role of strong beliefs in steering the actions of individuals is paramount. In this regard, Cunningham et al. (2004) believe that teachers' perceived beliefs guide their classroom instruction. Of course, it is logical to expect that ifteachers' beliefs are ineffective, they present misrepresentations of phonological instructions leading to a great confusion among learners. For Richards and Lockhart (1994), teachers' actions mirror their inner beliefs. 
Similarly, EFL teachers' responses on the awareness component were modest showing teachers as uncertain about the terms under investigation. Although teachers were not at their best on this part of the test, their responses on segmenting, rhyming, deleting and blending were similar; teachers' awareness about the four concepts is similar. However, it is worth noting that participants were more comfortable with segmenting and rhyming than with deleting and blending. On the other hand, EFL teachers did not do better on classroom literacy practices. In fact, their reported responses indicated the absence of best practices. Within this level of literacy practices vs. PA skills, results revealed a shortage in classroom literacy practices where children receive little hands-on experience activities to play with the sounds of the language. Teachers need help in filling the void in their competency and skills in order to enhance their literacy instructions. If there is one thing that these results convey, it is the fact that EFL teachers should know how to bring literacy into their classrooms. This accords well with other studies holding teachers responsible for bringing literacy interactions and quality instructions into their classrooms (Cárnio, Vosgrau \& Soares, 2017; Connor, Jakobsons, Crowe \& Meadows, 2009; Kennedy, 2013; Piasta \& Wagner, 2010; Ponitz \& Rimm-Kaufman, 2011; Washborn, Mulcahy \& Musante, 2017).

The other part of this study focused on the effect of teachers' gender, experience and qualifications on their classroom literacy instruction. Teachers' gender showed up as a factor that affect their beliefs, awareness and practice related to PA, favoring females over male teachers. It seems plausible to suggest that female instructors if equipped with the necessary knowledge and beliefs would be effective teachers for early grades. It is hard to say whether this is a trend or just a special-case result, but what can be stressed here is the probability of females being more appropriate to instruct early graders for reasons that may have to do with the mere fact that females are a better fit with early childhood than males. A similar stance was reported by Lam et. al, (2010), Lee, Rhee, \& Rudolf, (2018), Luschei(2011) and Oregan (2007) who concluded that students' performance improved in reading when instructed by a female teacher.

Previous experiences become the refuge only when our new experiences are limited. This aligns with the findings of Cheng and Zamarro (2016) where teachers' earlier experience plays a major role in shaping and defining their daily classroom practices and instruction. In this study, teachers' experience appears as an important factor that affects teachers' knowledge and beliefs. Specifically, teachers with four to seven years of experience possessed better knowledge about PA when they are compared with teachers from the other experience groups. Furthermore, teachers with 12 years and more of experience possessed stronger beliefs about the importance of PA in literacy instruction, when compared with the other teachers. This is consistent with the fact that beliefs normally takes time to be developed, therefore with more years of experience teachers come to the realization of the importance of PA in literacy instruction. This means there is a chance for EFL teachers to develop their beliefs about instructing early graders in reading, and it seems to advance with the longer years of experience. This opens the door to raise an issue about the reasons behind teachers changing their beliefs. This could be because of the exposure to new inputs in teaching reading such as training workshops that would challenge and possibly update their old beliefs.

To continue looking into the combination resulting out of the interaction of the earlier mentioned components of the study, results reported an impact for gender and experience on EFL teachers' knowledge, beliefs and practices. By the same token, results also reported an impact resulting from the interaction between experience and qualification on EFL teachers' knowledge, beliefs and practices. Also reported was an impact related to the interaction of gender and qualification which proved effective on EFL teachers' knowledge and practices. Finally, when considering the interaction of the three variables of gender, experience and qualification all together, results confirmed their effect on EFL teachers' knowledge, beliefs and practices. However, the results did not reflect specific pattern of the effect of the interaction among gender, experience and qualification on shaping literacy instruction.

\section{Conclusion}

Families, schools and stakeholders long for developing good readers (Ponitz \& Rimm-Kaufman, 2011) and would do all it takes to save young children from becoming illiterate or low achievers (Anthony \& Farncis, 2005; Share \& Stanovich, 1995; Snowling, 1998). The landmark study of Moats (1994) revealed deficits in teacher preparation, teachers' knowledge and beliefs, and hanged the bell for further studies. Since then, a flow of research has targeted teacher education advocating for teachers being competent in PA (Carlisle, Kelcey, Rowan, \& Phelps, 2011; Kennedy, 2013; Moats, 2009; Washburn et al., 2011a, 2011b; Washburn et al., 2017).

This research study aimed at investigating EFL teachers' knowledge, beliefs, awareness and practices related to PA. The findings demonstrated that most EFL teachers lack the basics in teaching children how to read. In addition, the study targeted the effect of the interaction between the EFL teachers' PA knowledge, beliefs, awareness and practices on the one hand and gender, experience and qualifications on the other. Findings reported gender and experience as plausible factors that would affect EFL teachers' instruction. Results also reported EFL teachers using more of their previous experiences to guide their classroom instruction.

This study adds to the body of literature that targets the role of teachers in raising literate EFL children. The 
study sheds light on the status quo of EFL in-service teachers' competency and brings to the attention of every stakeholder the critical role EFL teachers play in helping EFL children become readers. Although the results point towards teachers as possible cause behind children's low-literacy level, this study raises important questions for further investigations.

The researchers extend their recommendations to all stakeholders to consider the results and call for a comprehensive review of the curriculum, textbooks and teacher education programs. The researchers also call for more research to further investigate the reasons behind EFL children's struggle in becoming good readers of English language.

\section{References}

Abbot, M., Walton, C., \& Greenwood, C. R. (2002). Phonemic awareness in kindergarten and first grade. Teaching Exceptional Children, 34(4), 20-26.

Adams, M. J. (1990). Beginning to read: Thinking and learning about print. Cambridge, MA:IT Press.

Adams, M., \&Bruck, M. (1995). Resolving the great debate. American Educator, 19 (2), 7-21.

Alghazo, E. \& Al-Hilawani, Y. (2010). Knowledge, skills, and practices concerning phonological awareness among early childhood education teachers. Journal of Research in Childhood Education, 24, (2) 172-185.

Alhabahba, M. M., Pandian, A. \& Mahfoodh, O. H. A. (2016). English language education in Jordan: Some recent trends and challenges. Cogent Education, 3: 1156809. http://dx.doi.org/10.1080/2331186X.2016.1156809.

Al-Hazza, T., Fleener, C., \& Hager, J. (2008). Primary teachers' knowledge and knowledge calibration of early literacy practices. The Reading Matrix, 8, 1.

Author et al. (2013). Are Jordanian students phonemically aware? A descriptive study. Journal of Educational and Psychological Sciences, 14, (2), 37-53.

Annemarie H. Hindman, Barbara A.Wasik. (2008). Head Start teachers' beliefs about language and literacy instruction. Early Childhood Research Quarterly, 23, 479-492.

Anthony, L., \& Francis, D. (2005) Development of Phonological Awareness. American Psychological Society, 14 (5), 255-258.

Blachman, B. A. (2000). Phonological awareness. In M. L. Kamil, P. B. Mosenthal, P. D.

Bos, C., Mather, N., Dickson, S., Podhajski, B., \& Chard, D. (2001). Perceptions and Knowledge of Preservice and Inservice Educators About Early Reading Instruction. Annals of Dyslexia,51, 97-120. Retrieved from http://www.jstor.org/stable/23765365

Burgess, Kathleen A.; Lundgren, Kristin A.; Lloyd, John Wills; Pianta, Robert C. (2001). Preschool Teachers' Self-Reported Beliefs and Practices about Literacy Instruction. Center for Educational Research and Improvement (CIERA) ED. Ann Arbor, Michigan. Retrieved from https://files.eric.ed.gov/fulltext/ED452513.pdf

Carlisle, J. F., Kelcey, B., Rowan, B., \& Phelps, G. (2011). Teachers' knowledge about early reading: effects on students' gains in reading achievement. Journal of Research on Educational Effectiveness, 4, $289-321$. http://dx.doi.org/10.1080/19345747.2010.539297.

Cárnio, Maria Silvia, Vosgrau, Jéssica Sales, \& Soares, Aparecido José Couto. (2017). The role of phonological awareness in reading comprehension. Revista CEFAC, 19(5), 590-600. https://dx.doi.org/10.1590/19820216201619518316

Catts, W., Bridges, M., Little, D., \& Tomblin, J. (2008). Reading Achievement Growth in Children With Language Impairments. Journal of Speech, Language, and Hearing Research, 51, 569-1579. doi:10.1044/10924388(2008/07-0259)

Chen, R. J. (2010). Investigating models for preservice teachers' use of technology to support student-centered learning. Computers \& Education, 55(1), 32-42.

Cheng, A. \&Zamrro, G. (2016). Measuring teacher conscientiousness and its impact on students: Insight from the Measures of Effective Teaching longitudinal database (EDRE Working Paper 2016-05). Fayetteville, AR: Department of Education Reform, University of Arkansas.

Connor, C.,Jakobsons, J., Crowe E.,\& Meadows, J. (2009). Instruction, differentiation, and student engagement in Reading First classrooms. Elementary School Journal, 109, 3, 221-250.

Cunningham, A. E, Perry, K. E. Stanovich, K. E., \&Stanovich, P. J. (2004). Disciplinary knowledge of k-3 teachers and their knowledge calibration in the domain of 10 early literacy. Annals of Dyslexia, 54 (1),418-430.

Driver, M., Pullen, P., Kennedy, M., Williams, M., \& Ely, E. (2014). Phonological awareness using instructional technology to improve preservice teachers' knowledge. Teacher Education and Special Education, 1, 21. DOI: $10.1177 / 0888406414537902$

Dow, R. \& Baer, G. (2006). Self-paced phonics: A text for educators, (4th ed.). Boston: Prentice Hall.

Education First English Proficiency Index. (2014). Fourth edition of the EF English proficiency index. Retrieved from http://media.ef.com/_/ /media/centralefcom/epi/v4/ downloads/ full-reports/ef-epi-2014-english.pdf

Evans, M. A., Fox, M., Cremaso, L., \& McKinnon, L. (2004). Beginning Reading: The Views of Parents and 
Teachers of Young Children. Journal of Educational Psychology, $96 \quad$ (1), 130141.http://dx.doi.org/10.1037/0022-0663.96.1.130

Foulin, J. (2005). Why is letter-name knowledge such a good predictor of learning to read? Reading and Writing, 18, 2, 129-155. doi.org/10.1007/s11145-004-5892-2

Francis, D., Shaywitz, S., Stuebing, K., Shaywitz, B. \& Fletcher, J. (1996). Developmental lag versus deficit models of reading disability: A longitudinal, individual growth curves study. Journal of Educational Psychology, 88, 3-17.

Frey, B., Lee, S., Tollefson, N., Pass, L., and Massengill, D. (2005) Balanced Literacy in an Urban School District. Journal of Educational Research, 98 (5), 272-280.

Hoy, K.; Tarter, C.; Hoy, A. (2006). Academic Optimism of Schools: A Force for Student Achievement.American Educational Research Journal, 43, 3, 425 - 446 https://doi.org/10.3102/00028312043003425

Huffman, R., Speer, W. (2000). Academic Performance among At-Risk Children: The Role of Developmentally Appropriate Practices. Early Childhood Research Quarterly, 15, 2, (167-84).

Juel, C. (1988). Learning to read and write: A longitudinal study of 54 children from first through fourth grades. Journal of Educational Psychology, 80, 437-447.

Kennedy, M., Driver, M., Pullen, P., Ely, E.\& Cole, M. (2013). Improving teacher candidates' knowledge of phonological awareness: A multimedia approach. Computers \& Education 64, 42-51.

Lam, Y. H., Tse, S. K., Lam, J. W. \& Loh, E. K. (2010). Does the gender of the teacher matter in the teaching of reading literacy? Teacher gender and pupil attainment in reading literacy in Hong Kong. Teaching and Teacher Education 26, 754-759.

Lee, B., Cawthon, S., Dawson, K. (2013). Elementary and secondary teacher self-efficacy for teaching and pedagogical conceptual change in a drama-based professional development program. Teaching and Teacher Education, 30, 84-98.

Lee, J., Rhee, D., \& Rudolf, R. (2018). Teacher Gender, Student Gender, and Primary School Achievement: Evidence from Ten Francophone African Countries. The Journal of Development Studies, https://doi.org/10.1080\%2F00220388.2018.1453604

Luschie, T. F. (2011). The effectiveness and distribution of male primary teachers: Evidence from two Mexican states. International Journal of Educational Development, 32 (1), 145-154.

Mather, N., Box, C., \& Babur, N. (2001). Perceptions and knowledge of preservice and inservice teachers about early literacy instruction. Journal of Learning Disabilities, 4,471-482.

May M.H. Cheng, Kwok-Wai Chan, Sylvia Y.F. Tang, Annie Y.N. Cheng. 2009. Pre-service teacher education students' epistemological beliefs and their conceptions of teaching. Teaching and Teacher Education, 25, 319327.

McCutchen, D., Abbott, R. D., Green, L. B., Beretvas, S. N., Cox, S., Potter, N. S., Quiroga, T., \& Gray, A. L. (2002). Beginning literacy: Links among teacher knowledge, teacher practice, and student learning. Journal of Leraning Disabilities, 35, 69-86.

McCutchen, D., Harry, D. R., Cox, S.,Sidman, S.,Covill, A. E.,\&, Cunningham, A. E. 2003. Reading teachers' knowledge of children's literature and English phonology. Annals of Dyslexia, 53, 1, 23-45.

Ministry of Education. (2006). Directorate of Educational Research and Development. National Education Strategy. Amman.

Moats, L.C. (2009). Knowledge foundations for teaching reading and spelling. Reading and Writing: An Interdisciplinary Journal, 22, 379-399.

Moats, L. C., \&Foorman, B. R. (2003). Measuring teachers' content knowledge of language and reading. Annals of Dyslexia, 53, 23-45.

Morris, D. (2011). Interventions to develop phonological and orthographic systems. In A. McGill-Franzen, \& R. L. Allington (Eds.), Handbook of reading disability research (pp. 279-288). New York, NY: Routledge.

Mullis, I. V., Martin, M. O., Foy, P., \& Arora, A. (2012). Trends in international mathematics and science study (timss) 2011 international results in mathematics. Boston, MA: International Association for the Evaluation of Educational Achievement.

National Reading Panel (2000). Teaching children to read. National Institute of child Health and Human Development, NationalInstitute of Health, pub. No. 00-4769.

ORegan, B. (2007). Females better at teaching reading to boys: Study. Retrieved July 25, 2018, from http://www.nowpublic.com/females-better-teaching-reading-boys-study

Pearson,\& R. Barr (eds.), Handbook of reading research (Vol. 3, pp. 251-284). Mahway, JN: Lawrence Erlbaum Associates.

Piasta, S. B., \& Wagner, R. K. (2010). Learning letter names and sounds: Effects of instruction, letter type, and phonological processing skill. Journal of Experimental Child Psychology, 105, 324-344.

PISA (2012). Jordan: Student performance. OECD. http://gpseducation.oecd.org/ Country Profile?primaryCountry $=$ JOR\&treshold $=10 \&$ topic $=$ PI 
Ponitz, C. C., Sara E. Rimm-Kaufman. (2011). Contexts of reading instruction: Implications for literacy skills and kindergarteners' behavioral engagement. Early Childhood Research Quarterly,26, 157-168.

Pullen, P. C. (2004). Effective practices for phonological awareness. Teaching LD HotSheet, 2, Retrieved from. http://TeachingLD.org/hot_sheets/.

Richgels, D., J. (2001). Phonemic awareness. The Reading Teacher, 55, 3, 274-278.

Share, D. L., \&Stanovich, K. E. (1995). Cognitive processes in early reading development: Accommodating individual differences into aodel of acquisition. Issues in Education: Contributions from Educational Psychology, 1, 1-57.

Snow, C. E., Burns, M. S., \& Griffin, P. (1998). Preventing reading difficulties in young children. Washington, DC: National Academy Press.

Snowling, M. (1998). Reading development and its difficulties. Educational and Child Psychology, 15, 44-58.

Spear-Swerling, L., Brucker, P. O., \&Alfano, M. P. (2005). Teachers' literacy-related

knowledge and self-perceptions in relation to preparation and experience. Annals of Dyslexia, 55, 266-296.

Tibi, S. (2005).Teachers' Knowledge and Skills in Phonological Awareness in United Arab Emirates.International Journal of Special Education, 20 (1), 60-66.

Troyer, S. J., \&Yopp, H. K. (1990). Kindergarten teachers' knowledge of emergent literacy concepts. Reading Improvement, 27, 34-40.

Vadasy, P. F., Sanders, E. A., \& Peyton, J. A. (2006). Code-oriented instruction for kindergarten students at risk for reading difficulties: A randomized field trial with paraeducator implementers. Journal of Educational Psychology, 98, 3, 508-528.

http://dx.doi.org/10.1037/0022-0663.98.3.508

Verhoeven L. (2000). Components in early second language reading and spelling. Scientific Studies of Reading, 4, 4, 313-330. doi: 10.1207/S1532799XSSR0404_4.

Vellutino, F., Fletcher, J., Snowling, M., \& Scanlon, D. (2004). Specific reading disability (dyslexia): what have we learned in the past four decades? Journal of Child Psychology and Psychiatry, 45 (1), 2-40.

Verhoeven L. \&Leeuwe J. (2011). Role of gender and linguistic diversity in word decoding development. Learning and Individual Differences, 21,359-367. doi: 10.1016/j.lindif.2011.02.004.

Vellutino, F., Scanlon, D., \&Tanzman, M. (1994). Components of reading ability. In G. Lyon (Ed.), Frames of reference for the assessment of learning disabilities. Baltimore, MD: Paul H. Brookes.

Wharton- McDonald, R. (2011). Expert classroom instruction for students with reading disabilities. In A. McGillFranzen\& R. L. Allington (Eds.), Handbook of reading disability research (pp. 265-272). New York: Routedge.

Washborn, E. K.; Mulcahy, C. A. \&Musante, G. (2017). Novice Teachers' Knowledge of Reading-related Disabilities and Dyslexia. A Contemporary Journal, 15 (2), 169-191.

Washburn, E. K, Joshi, R. M., \& Cantrell, E. B. (2011a). Are preservice teachers prepared to teach struggling readers? Annals of Dyslexia, 61, 21-43.

Washburn, E. K, Joshi, R. M., \& Cantrell, E. B. (2011b). Teacher knowledge of basic language concepts and dyslexia. Dyslexia, 17, 165-183.

Yopp, H.K. (1992). Developing phonemic awareness in young children. The Reading Teacher, 45, 696-703.

Yopp, H.K. (1995). Read-aloud books for developing phonemic awareness: An annotated bibliography. The Reading Teacher, 48, 538-542. 